\title{
Fattening performance and carcass traits of implanted and supplemented grassfed bulls
}

\author{
Desempeño en la ceba a pastoreo y rasgos de la canal de toros implantados y \\ suplementados
}

\begin{abstract}
Nelson Huerta-Leidenz',2* (iD, Nancy Jerez-Timaure ${ }^{1,3}$ iD, Susmira Godoy ${ }^{4}$ iD, Carlos Rodríguez-Matos ${ }^{5}$ y Omar Araujo-Febres $^{1}$ iD
${ }^{1}$ Facultad de Agronomía, Departamento de Zootecnia, Universidad del Zulia. Maracaibo, Venezuela. ${ }^{2}$ Department of Animal and Food Sciences, Texas Tech University. Texas, USA. ${ }^{3}$ Instituto de Ciencia Animal, Facultad de Ciencias Veterinarias, Universidad Austral de Chile. Valdivia, Chile. ${ }^{4}$ Instituto Nacional de Investigaciones Agrícolas. Centro Nacional de Investigaciones Agropecuarias. Maracay, Aragua, Venezuela. ${ }^{5}$ Hato Santa Luisa C. A. Caracas, Venezuela. *Email: nelson.huerta@ttu.edu
\end{abstract}

\begin{abstract}
Ninety-nine uncastrated males were randomly distributed into four grazing groups to examine variation in growth and carcass traits, due to the implant regime [Implantation of 72 miligrams $(\mathrm{mg})$ of Ralgro $®$ at day (d) 0 followed by its reimplantation at $d 90$ versus implantation of Revalor $\AA$ at d 0 followed by $72 \mathrm{mg}$ of Ralgro $\circledR$ at d 90)], and suplementation type [mineral supplementation (MS) versus strategic supplementation (SS)]. With a $2 \times 2$ factorial arrangement, the analysis of variance included the treatments and their interaction (implant regimen $x$ supplementation) as fixed effects, and the breed type as a random effect. The interaction was not significant; neither did the implant regimen on any growth trait $(P>0.05)$. Compared to $M S$, the SS group had a greater daily weight gain (779 vs. 541 grams; $P<0.001)$, required a shorter (38.3 d lesser) time of fattening to reach the end point (198.3 versus $236.6 \mathrm{~d} ; \mathrm{P}<0.001)$ with a heavier liveweight $(498.2$ vs. 474. 4 kilograms; $P=0.02)$ at an earlier age (29.4 vs. 30.8 months; $P<0.001)$, with a higher carcass dressing percentage (59.13 vs $57.62 \% ; P=0.03)$ and younger carcass bone maturity $(P<0.001)$. With the exception of thoracic depth, carcass traits did not vary with the implant regimen $(P>0.05)$. Both implant regimens are comparable in their effects on the fattening performance and commercially important carcass traits of grassfed bulls. SS is a feasible practice to improve fattening performance of grazing bulls but no beneficial impact on their carcass quality was expected.
\end{abstract}

Key words: Strategic supplementation; implants; bull; beef carcass; Brahman

\section{RESUMEN}

Noventa y nueve machos sin castrar se distribuyeron al azar en cuatro grupos a pastoreo para examinar la variación en rasgos de crecimiento y en canal, debida a régimen de implantes [72 miligramos (mg) de Ralgro® el día (d) 0 seguido de su reimplante el d 90 versus implantación de Revalor ${ }^{\circledR}$ el d 0 seguido de $72 \mathrm{mg}$ de Ralgro® el d 90] y suplementación [mezcla mineral $(\mathrm{SM})$ versus suplemento estratégico (SE)]. El análisis de varianza con arreglo factorial $2 \times 2$ incluyó, como efectos fijos, los tratamientos y su interaccion (régimen de implantes $x$ suplementación) y tipo racial como efecto aleatorio. En rasgos de crecimiento, la interacción no fue significativa $(P>0,05)$; tampoco lo fué el régimen de implante $(P>0,05)$. El grupo con $S E$, con respecto al que recibió $S M$, tuvo mayor ganancia diaria de peso (779 vs. 541 gramos; $\mathrm{P}<0,001$ ) requirió 38,3 d menos de ceba [(198,3 versus 236,6 d; $(P<0,001)]$ para alcanzar mayor peso vivo final $(498,2$ versus 474,4 kilogramos; $P=0,02)$ a una edad más temprana $(29,4$ versus 30,8 meses; $P<0,001)$, con mayor rendimiento en canal $(59,13$ versus $57,62 \% ; P=0,03)$ y una menor madurez ósea de la canal $(P<0,001)$. A excepción de la profundidad torácica, los rasgos en canal no variaron con el régimen de implantes $(P>0,05)$. Los dos regímenes agresivos de implantes aquí evaluados son equiparables en sus efectos sobre el desempeño en la ceba y caracteristicas comercialmente importantes de la canal. La SE es una práctica factible para mejorar el desempeño de toros en la ceba a pastoreo, pero no puede esperarse beneficio alguno en la calidad de sus canales.

Palabras clave: Suplementación estratégica; implantes; toros; canales, Brahman 
Responses to implants and supplementation of grazing bulls / Huerta-Leidenz et al.

\section{INTRODUCTION}

With the construction of dikes (modules) to control floods and to have water available during the dry season [32], the native vegetation of the lower plains of Apure State (Venezuela) has been replaced with better forage (e.g., Brachiaria spp.) resources [21]. However, during the seasonal drought, the nutritional quality of cultivated grasses can drop to levels that impair the biological response of genetically improved cattle [27] even with mineral or mineral-protein supplementation [9].

The unsuccessful attempts to improve the response of cattle with greater genetic potential indicate the need for ad hoc application of technological packages; particularly, when the ranchers in the area intend to fatten cattle at the same breeding operation and harvest them in packing houses authorized for carcass classification and grading, hoping for a better return on investment [17, 29, 30]. Synthetic anabolic implants, based on steroidal compounds such as trenbolone acetate $+17 \beta$-estradiol (ATB + E17) and non-steroidal, estrogenic compounds, such as Zeranol (a lactone of resorcylic acid, Ralgroß) constitute technological resources widely used to improve the response in productive performance and the lean: fat ratio in carcasses of castrated males (steers); especially under intensive fattening in North America [1, 3, 33]. On the contrary, few studies have evaluated the response of entire males (bulls or bullocks) to anabolics, yielding null or inconsistent results [12, 23 - 25]. Potent implants (e.g., ATB + E17), as well as more aggressive anabolic combinations or strategies, administered to predominantly Bos taurus steers during intensive fattening, have negatively affected marbling level and the U.S.carcass quality grade [33].

These findings suggest that aggressive implant regimes used to improve fattening performance in grazing bulls with Bos indicus genetics, may have a more detrimental impact on carcass quality. In the low ("modulated') plains of Apure, improvements have been observed in the growth rate of steers and bulls, fattened to grazing with a strategic (catalytic) supplement [6] and in the same ranch an additive supplementation brought about improvements in quality traits of bull carcasses [17]. As the vast majority of cattle in Venezuela are fattened on pasture, there is interest in evaluating the effect of more aggressive implant regimes on the performance of bulls under grazing conditions with a strategic supplementation.

Therefore, the objective of this trial was to examine the responses to aggressive implant regimes and strategic supplementation in growth and carcass traits of bulls, fattened to pastures of cultivated grasses in the lower plains of Apure State.

\section{MATERIALS AND METHODS}

\section{Trial location}

The trial was carried out in a commercial ranch located in the low flood plains of the Apure State (Venezuela). The ecological and soil conditions of the area have been widely described [16, 17, 30, 31, 33]. The ranch has an infrastructure of dikes (modules) for flood control. The grazing module (485 hectares - ha-) consists of 61 paddocks of 7.4 ha each with cultivated pastures and equipped with electric fences (Gallaguer $®$ model- 6 wire electric fences, Australia).

\section{Animal handling}

The animals were grown on the same ranch, so that their management before the grazing trial was very similar. Cattle were dewormed against ecto - and endo-parasites and vaccinated against rabies and foot-and-mouth disease before entering the fattening module on November 14, 1995 when the treatments began. Trained technicians followed the criteria for animal care and welfare described in the Bioethics and Biosafety guide of the Venezuelan Fund for Scientific and Technological Research (FONACIT) [13].

The trial included a total of 99 contemporary intact males (bulls). At the beginning of the trial, the age was $23.0 \pm 0.85$ months (mo.), and the average live weight (LW) was $347.1 \pm 27.9$ kilograms $(\mathrm{kg})$ as determined by a Fairbank-Morse $®$ Livestock, single-animal Scale, LSA series model (USA). According to the feeder cattle grading standards [28] the average frame size was $2.18 \pm 0.6$ (medium) with a muscle thickness of $2.05 \pm 0.6$ (medium). The bulls were randomly assigned to the four treatment groups, optimizing the balance of observations by breed type, initial LW and treatment (TABLE I). To avoid the paddock's effect, the experimental groups were kept under rotational grazing with seven (days) d of occupation and $21 \mathrm{~d}$ rest intervals, in modules of cultivated grasses [Brachiaria arrecta (Tanner grass) and lesser proportion Cynodon nlemfluensis (Star grass), Brachiaria mutica (Pará grass) and Echinochloa polystachya (German grass)].

TABLE I

Experimental design indicating distribution of observations by breed type, supplementation treatment and implant regime

\begin{tabular}{cccccc}
\hline & \multicolumn{4}{c}{ Treatment $^{1,2}$} & \\
\cline { 2 - 4 } Breed type $^{3}$ & \multicolumn{3}{c}{ Ralgro-Ralgro Revalor-Ralgro } & Total \\
\cline { 2 - 4 } & SS (n) & MS (n) & SS (n) & MS (n) \\
\hline Brahman & 3 & 3 & 3 & 3 & 12 \\
F1-Angus & 3 & 4 & 3 & 6 & 16 \\
F1-Romosinuano & 3 & 5 & 3 & 5 & 16 \\
F1-Senepol & 4 & 5 & 2 & 5 & 16 \\
F1-Simmental & 4 & 5 & 3 & 5 & 17 \\
Brahman cross & 2 & 3 & 4 & 3 & 12 \\
3/4 Bos taurus & 3 & 3 & 2 & 2 & 10 \\
Total & 22 & 28 & 20 & 29 & 99 \\
\hline
\end{tabular}

${ }^{1}$ Implant regime: Ralgro-Ralgro corresponds to double-dosis (72 $\mathrm{mg}$ ) of Ralgro ${ }^{\circledR}$ at day 0 followed by a second dosis of $72 \mathrm{mg}$ of Ralgro ${ }^{\circledR}$ at day 90; Revalor-Ralgro corresponds to a first dosis of Revalor ${ }^{\circledR}$ at day 0 , followed by a second dosis $(72 \mathrm{mg})$ of Ralgro ${ }^{\circledR}$ at day $90 .{ }^{2}$ Supplementation treatment: mineral supplementation as a positive control (MS) vs. strategic supplementation (SS). ${ }^{3}$ Breed types described as: F1-Angus, F1-Romosinuano, F1-Senepol, and F1-Simmental were obtained by artifical insemination of purebred Brahman cows with semen from bulls of Angus, Romosinuano, Senepol and Simmental breeds, respectively; Brahman cross derived from a herd of Brahman cross cows bred with purebred Brahman bulls; the $3 / 4$ Bos taurus were obtained by natural mating of purebred Romosinuano bulls with F1-Romosinuano x Brahman cows; $\mathrm{n}=$ number of observations. 


\section{Implant regimens}

Two implant regimens were considered: (I) implantation of zeranol (Ralgro $®)$ at double dose [72 miligrams (mg); (2x-Ralgro®)] on d 0 , with reimplantation (2x-Ralgro $($ ) $)$ at $90 \mathrm{~d}$ (Ralgro - Ralgro) and (II) implantation of Revalor $(20 \mathrm{mg}$ of $17 \beta$ - estradiol $+140 \mathrm{mg}$ of Trenbolone acetate) on $\mathrm{d} 0$, with reimplantation of $2 \mathrm{x}$-Ralgro $®$ at $90 \mathrm{~d}$ (Revalor-Ralgro). The implants were subcutaneously placed at the base of the ear of each animal following the manufacturer's instructions. The two implant regimens were randomly assigned to the groups subjected to the supplementation treatments.

\section{Supplementation treatments}

The supplementation effect was measured by comparing the traditional practice of mineral supplementation (MS) against a strategic supplementation (SS). The MS group received the complete mineral mixture at a rate of $80 \mathrm{grams}(\mathrm{g}) \cdot \operatorname{animal}^{-1} \cdot \mathrm{d}^{-1}$, offered continuously, at will. This MS contained $\mathrm{P}$ and $\mathrm{Ca}$, and other macro and micro elements to complement the mineral contribution of the forage (TABLE II). The SS group was manually fed with a supplement $\left(1 \mathrm{~kg} \cdot \mathrm{d}^{-1}\right)$ with a low ruminal load (catalytic) that contained hydrolyzed feather meal, cane molasses, rice polish, a mineral premix with $\mathrm{P}$ and $\mathrm{Ca}$ and an ionophore (Salocin ${ }^{\circledR}$ ) during d 0 -d 60 of the trial (Strategic Supplement-Phase 1; TABLE II). From d 61 to $d$ 182, they received a concentrate (Strategic SupplementPhase 2; TABLE II), which contained the same ingredients of the Strategic Supplement-Phase 1, but in different proportions when adding whole cottonseed, encapsulated bypass fat: ether extract (EE): $22.4 \%$, as an additional source of bypass protein with low ruminal degradability. Protein sources contributed $87.2 \%$ of the total crude protein (CP) of the supplement $(54.7 \%$ cottonseed and $32.5 \%$ feather meal), with a high proportion $(50-70 \%)$ of bypass protein. The supply of the Strategic Supplement-Phase 2 was maintained for ca. $122 \mathrm{~d}$ (until the beginning of August, the rainy season).

\section{Growth performance and endpoint criteria}

The average daily gain (ADG), was determined for the total period of permanence in the module. The average LW at the end of the fattening period was $484.52 \pm 34.70 \mathrm{~kg}$. Bulls were sent to harvest when reaching a satisfactory conformation, as determined by the visual evaluation of three judges, and/or the stability of the daily gain/loss, once a LW of $475 \mathrm{~kg}$ of weight was exceeded. The average shipping LW for transportation to the harvest plant was $509.51 \pm 31.70 \mathrm{~kg}$. The distribution of harvest lots with different fattening $\mathrm{d}$, by treatment, is presented in TABLE III.

\section{Harvest and carcass evaluation}

Dressing procedures and post-mortem inspection in the harvest facility (Matadero Industrial Centro Occidental de Barquisimeto) were carried out in accordance with Venezuelan standards [7]. The hot carcass was weighted and five linear measurements were taken before chilling (width and circumference of the thigh, length of the pelvic limb, carcass length, and thorax depth), according to Huerta-Leidenz et al. [15]. After refrigeration for 48 hours (h) at $4{ }^{\circ} \mathrm{C}$ (using a Vilter ${ }^{\circledR}$ Cooler Ammonia Diffusers, Model UF-42-411/2-RA-HGP, USA), the chilled left sides were quartered between the $12^{\text {th }}$ and $13^{\text {th }}$ rib. Two experienced judges assigned scores for conformation and exterior fat finish, marbling level, physiological
TABLE II

Composition of the forage supplements used in the trial

\begin{tabular}{|c|c|c|c|}
\hline \multirow{2}{*}{$\begin{array}{l}\text { Composition } \\
\text { Ingredient,\% }\end{array}$} & \multicolumn{3}{|c|}{ Supplement ${ }^{1}$} \\
\hline & $\begin{array}{c}\text { Strategic- } \\
\text { Phase } 1\end{array}$ & $\begin{array}{c}\text { Strategic- } \\
\text { Phase } 2\end{array}$ & Mineral \\
\hline Feather meal & 10.0 & 10.0 & - \\
\hline Whole cottonseed & 0.0 & 49.9 & - \\
\hline Rice polish & 77.0 & 27.1 & - \\
\hline Cane molasses & 5.0 & 5.0 & - \\
\hline Mineral premix & 7.0 & 7.0 & - \\
\hline Ionophore $^{2}$ & 1.0 & 1.0 & - \\
\hline \multicolumn{4}{|l|}{ Nutrient } \\
\hline $\mathrm{EME}, \mathrm{kcal} / \mathrm{kg}$ & 2.514 & 2.809 & - \\
\hline $\mathrm{PC}, \%$ & 17.78 & 25.82 & - \\
\hline$P, \%$ & 1.07 & 0.79 & 12.0 \\
\hline $\mathrm{Ca}, \%$ & 0.12 & 0.17 & 24.0 \\
\hline $\mathrm{Mg}, \%$ & - & - & 1.5 \\
\hline $\mathrm{S}, \%$ & - & - & 1.0 \\
\hline $\mathrm{Mn}, \%$ & - & - & 0.50 \\
\hline $\mathrm{Zn}, \%$ & - & - & 0.75 \\
\hline $\mathrm{Fe}, \%$ & - & - & 0.50 \\
\hline $\mathrm{Cu}, \%$ & - & - & 0.20 \\
\hline $\mathrm{Co}, \%$ & - & - & 0.004 \\
\hline $\mathrm{I}, \%$ & - & - & 0.02 \\
\hline $\mathrm{Se}, \%$ & - & - & 0.004 \\
\hline
\end{tabular}

${ }^{1}$ Strategic supplement-Phase 1 was supplied in the first 60 days of the trial; Strategic supplement-Phase 2 was administered manually from day 60 to day 182 (122 days in total) at a rate of $1 \mathrm{~kg} \cdot$ animal $^{-1} \cdot$ day $^{-1}$. The mineral supplement was offered to the control (MS) group throughout the test with free access $\left(80 \mathrm{~g} \cdot\right.$ animal $\left.^{-1} \cdot \mathrm{day}^{-1}\right) .{ }^{2}$ Salocin $®$ was used as the ionophore.

bone and lean maturities, rib eye area (REA), and back fat thickness over the REA (adjusted with the exterior fat finish) following the stipulated procedures [28, 35]. The adipose maturity was evaluated by the fat color, according to Decree 1896 [28]. The Venezuelan category and the U.S. quality grade were respectively estimated for each carcass [28, 35]. As the kidney, pelvic and peri-cardiac fat depots $(\mathrm{KPH})$ had been removed prior to carcass chilling, its weight, or proportion of the carcass weight could not be assessed. The US yield grade [35] of each bull carcass was estimated assuming a constant KPH percentage value of $1.88 \%$ according to previous data $[6,17]$. 
TABLE III.

Frequency distribution of harvest cattle lots by days of fattening required to reach end point by type of supplementation and implant regimen

\begin{tabular}{cccccc}
\hline \multirow{2}{*}{$\begin{array}{c}\text { Fattening } \\
\text { days }\end{array}$} & \multicolumn{3}{c}{ Type of Supplementation ${ }^{1}$} & \\
\cline { 2 - 4 } & \multicolumn{2}{c}{ SS } & \multicolumn{3}{c}{ MS } \\
\cline { 2 - 4 } & RAL-RAL REV-RAL & RAL-RAL REV-RAL & \\
\hline 181 & 5 & 7 & 0 & 1 & 13 \\
195 & 7 & 6 & 0 & 0 & 13 \\
209 & 7 & 5 & 3 & 2 & 17 \\
223 & 3 & 2 & 4 & 9 & 18 \\
237 & 0 & 0 & 12 & 9 & 21 \\
258 & 0 & 0 & 9 & 8 & 17 \\
$\mathrm{n}$ & 22 & 20 & 28 & 19 & 99 \\
\hline
\end{tabular}

'Supplementation treaments: whole mineral supplementation (MS); Experimental strategic supplementation (SS). ${ }^{2}$ Implant regimens: RAL-RAL corresponds to double-dosis implant $(72 \mathrm{mg})$ of Ralgro ${ }^{\circledR}$ at day 0 followed by a second dosis of $72 \mathrm{mg}$ of Ralgro ${ }^{\circledR}$ at day 90 ; REV-RAL corresponds to a first dosis of Revalor ${ }^{\circledR}$ at day 0 , followed by a second dosis (72 mg) of Ralgro ${ }^{\circledR}$ at day 90

\section{Statistical analyses}

The R software [11] was used for statistical analyses. Once the fulfillment of the assumptions of normality, independence and sphericity of the variables was verified, the analysis of variance (ANOVA) was performed with a mixed linear model, following a completely randomized design with a $2 \times 2$ factorial arrangement that included, as fixed effects, type of supplementation, implant regimen and their interaction. The breed type was included in the model as a random effect. The multiple comparison of means was made with the Tukey test $(\alpha=0.05)$. The type of supplementation $\mathrm{x}$ implant regimen interaction was not significant; neither was the effect of implant regime on growth traits $(P>0.05)$.

\section{RESULTS AND DISCUSSION}

\section{Pasture nutrient content}

The nutritional contribution of the pasture during the entire trial, with respect to its dry matter (DM) was estimated, on average: total digestible nutrients (TDN), $63 \%$; CP, $6 \%$; nitrogen free extract (NFE), $47 \%$; EE, $1 \%$; crude fiber (CF), $34 \%$; ashes; $11 \%$; calcium (Ca), $1.1 \%$; phosphorus (P), $0.32 \%$. In general, the average chemical composition of the pastures during the dry season, coincides with that reported by Tejos et al. [34] for the same paddocks, indicating a medium - to low-quality cultivated grasses [Tanner (Brachiaria arrecta), Star (Cynodon nlemfuensis), Pará (Brachiaria mutica) and German (Echinochloa polystachya)].

The content (\% DM) of average crude protein (CP) according to Tejos et al. [34] was one percentage point lower (ca. $5.0 \%$ ) than the value of this work's estimates. Assuming the bromatological values reported by Tejos et al. [34], the CP content of the pasture during the dry season could be lower than the cattle requirement (CP: $7 \%$ ) [26], while the content of macro - and micro-elements would present adequate values, with the only exception of copper, slightly lower than the required content $(\mathrm{Cu}: 10$ parts per million (ppm) [26].

\section{Effects of supplementation on fattening performance}

The mean values and standard error for growth traits and other performance indicators, according to the type of supplementation are given in TABLE IV. The SS group, outperformed the MS counterpart in ADG with an advantage of $227.7 \mathrm{~g}(P<0.001)$. With this faster growth rate, the SS group reached the end point more rapidly (a $38.3 \mathrm{~d}$ shorter fattening period; $\mathrm{P}<0.001$ ), $1.44 \mathrm{mo}$ younger $(P<0.001)$ and $23.81 \mathrm{~kg}$ heavier in final LW $(P=0.02)$.

ADG mean values in three consecutive, annual trials in the same ranch [34] were 587, 532 and $531 \mathrm{~g}$; all lower than the value found herein for the SS group (ca. $769 \mathrm{~g}$ ). A preliminary report from the present trial [5] indicated that the SS group had a faster growth rate during the first supplementation phase $(0-60 \mathrm{~d})$, and this increase in ADG was maintained for $150 \mathrm{~d}$; thereafter, the response was attenuated in relation to the MS group [5]. Also, Byers et al. [5] reported the total consumption of DM by the MS group vs. SS was 15.3 vs. $17.2 \mathrm{~kg} \cdot$ head $^{-1}$ or $84 \mathrm{vs.} 945 \mathrm{~g} \cdot \mathrm{d}^{-1}$ until d 182 [5]. The accelerated growth rate allowed SS cattle to be finished before the start of the rainy season and its commercialization had a price advantage, producing a $2: 1$ return on the SS investment [5].

The mean value for the SS final LW exceeds between 17 to $27 \mathrm{~kg}$ to those reported for bulls of similar age (29 to $30 \mathrm{mo}$ in the same ranch [34] with final LW of $471 \mathrm{~kg}$ (born in 2000), $481 \mathrm{~kg}$ (born in 2001) and $477 \mathrm{~kg}$ (born in 2002). The final LW of SS bulls also tends to be higher than those reported by Plasse et al. [27] for Brahman bulls and four groups of crosses 1/4 Bos taurus $3 / 4$ Bos indicus (462 kg at $30.6 \mathrm{mo}$ ) and for most of the breed types considered by Riera et al. [29]. The best indices of productive performance achieved with SS could be due to its protein sources of low ruminal degradability, such as hydrolyzed feather meal and cottonseed, which have been shown to favor a slow release of nitrogen $(\mathrm{N})$ in the rumen, increasing the efficiency of the microbiota to synthesize proteins [4]. Furthermore, it is known that a large part of the bypass protein fraction is degraded in the intestine to peptides and amino acids that promote muscle protein synthesis [14]

The literature supports the provision of a high-protein supplement in small amounts (catalytic) to stimulate the consumption and digestion of poor-quality forages [8], and several studies have found that Nitrogen supplementation improves the utilization of tropical grasses $[4,20]$, by achieving a greater extraction of energy from the forage [10]. The bypass fat derived from the cottonseed included in the strategic supplement-phase 2 could also improve the digestible protein/digestible energy ratio and consequently, the efficiency and quantity of microbial protein [38]. On the other hand, the addition of ionophores to the diet is known to increase the ruminal synthesis of propionic acid, while reducing that of butyric and acetic acids, as well as the production of methane and ammonium; increasing the digestibility of DM, CP and fiber which optimizes the use of forages [2, 37, 39]. In sum, the change in the ruminal fermentation pattern induced by the ionophore could also favor the ADG in the SS group. 
TABLE IV

Effects of type of suplementation on growth performance traits of bulls during fattening on grass

\begin{tabular}{|c|c|c|c|c|}
\hline \multirow{2}{*}{ Variable } & \multicolumn{2}{|c|}{$\begin{array}{c}\text { Suplementation } \\
\text { Type }\end{array}$} & \multirow{2}{*}{ SEM $^{1}$} & \multirow{2}{*}{$P$ value } \\
\hline & $\begin{array}{c}\text { MS } \\
(n=57)\end{array}$ & $\begin{array}{c}\text { SS } \\
(n=42)\end{array}$ & & \\
\hline Hip height, cm & 134.29 & 134.60 & 0.96 & 0.50 \\
\hline Fattening days & 236.63 & 198.33 & 3.10 & $<0.001$ \\
\hline $\begin{array}{l}\text { Chronological } \\
\text { age (mo.) }\end{array}$ & 30.83 & 29.39 & 0.32 & $<0.001$ \\
\hline $\begin{array}{l}\text { Final liveweight } \\
\text { on test, } \mathrm{kg}\end{array}$ & 474.42 & 498.23 & 8.16 & 0.02 \\
\hline $\begin{array}{c}\text { Shipping } \\
\text { liveweight, kg }\end{array}$ & 510.73 & 507.86 & 7.68 & 0.46 \\
\hline$A D G, g$ & 541.32 & 769.01 & 33.14 & $<0.001$ \\
\hline
\end{tabular}

MS: Mineral supplementation; SS: Strategic supplementation. ADG: Average daily gain. ${ }^{1}$ Standard Error of Mean.

\section{Effects of supplementation on carcass traits}

SS only favored $(P<0.05)$ carcass dressing percentage and physiological bone maturity $(P<0.001)$ (TABLE V). Carcasses from the SS group significantly dressed 1.5 percentage points more than their MS counterparts. Also, SS carcasses exhibited a greater youth of the skeleton (bone maturity) than those from the MS group $(P<0.001)$, which corresponds to their younger chronological age at harvest (TABLE IV). Without reaching statistical significance, carcasses from bulls with SS tended to have a more abundant fat cover $(P=0.07)$, thicker back fat $(P=0.08)$ and a larger REA $(P=0.09)$. The tendency to a more desirable fat cover in carcasses from the group SS could be due to the surpassing fat provided by the cottonseed, which is hydrolyzed in the small intestine and absorbed for the synthesis of body fat [19].

Riera [30] evaluated the response to fattening of grazing bulls in the same ranch, with a supplement based on $30 \%$ corn flour, $20 \%$ chicken litter, $15 \%$ rice polish, $10 \%$ soybean (Glycine max), $10 \%$ corn cob, $10 \%$ molasses and $5 \%$ of meat and bone meal. This author [30] indicated that bull carcasses derived from the supplemented group had a more desirable conformation and fat cover scores, as well as a slightly more abundant marbling $(P<0.05)$. Also, Jerez-Timaure and Huerta-Leidenz [17] reported a significant increase in carcass weight, younger bone maturity, better conformation scores, thicker backfat and lesser yellowish fat color in the supplemented group of bulls with respect to the control when testing a supplement based on $41 \%$ chicken manure, $50 \%$ rice polish, $6 \%$ molasses, $1.5 \%$ salt, $1.5 \%$ mineral mixture and $0.83 \%$ Rumensin $®$ ) [17]. The significant improvements in quality traits related to carcass finish observed with other types of supplementation in the same ranch $[17,29,30$,$] may also be due to the fact that in these previous$ trials, the experimental groups of bulls were not implanted.

\section{Effects of implant regimens on fattening performance}

The variables indicating productive performance did not vary with the implant regimen $(P>0.05)$. Regrettably, the lack of a control (non-implanted) group of bulls in the present investigation does not allow to further infer about the growth promoting effects of these implant regimens. When experiments include a control (non-implanted) group, even under intensive fattening conditions no significant responses of bulls to the use of implants have been found $[24,25]$. Perhaps it is due to the interference of the endogenous production of androgens. In fact, grass-fed bulls implanted with zeranol before puberty have grown $4.8 \%$ faster than non-implanted bulls [22]; but after puberty, the response to this nonsteroidal implant

TABLE V

Effects of type of suplementation on carcass traits

\begin{tabular}{|c|c|c|c|c|}
\hline \multirow{2}{*}{ Variable } & \multicolumn{2}{|c|}{$\begin{array}{c}\text { Suplementation } \\
\text { type }\end{array}$} & \multirow{2}{*}{ SEM } & \multirow{2}{*}{$P$ value } \\
\hline & $\begin{array}{c}\text { MS } \\
(n=57)\end{array}$ & $\begin{array}{c}\text { SS } \\
(n=42)\end{array}$ & & \\
\hline Hot carcass weight, kg & 294.16 & 300.21 & 4.76 & 0.71 \\
\hline Dressing, $\%$ & 57.62 & 59.13 & 0.46 & 0.03 \\
\hline Conformation score ${ }^{a}$ & 3.57 & 3.62 & 0.18 & 0.24 \\
\hline Finish score ${ }^{b}$ & 3.63 & 3.05 & 0.16 & 0.42 \\
\hline Skeletal maturityc & 204.03 & 186.42 & 6.55 & $<0.001$ \\
\hline Lean maturiryc & 205.09 & 217.14 & 13.68 & 0.32 \\
\hline Overall maturityc & 205.44 & 201.90 & 9.25 & 0.47 \\
\hline Adipose maturity ${ }^{d}$ & 2.93 & 2.92 & 0.07 & 0.77 \\
\hline Ribeye area, $\mathrm{cm}^{2}$ & 81.75 & 83.64 & 2.66 & 0.09 \\
\hline Back fat thickness, mm & 1.37 & 1.76 & 0.29 & 0.07 \\
\hline Marbling score ${ }^{e}$ & 5.85 & 5.86 & 0.09 & 0.71 \\
\hline Thigh width, $\mathrm{cm}$ & 61.30 & 62.37 & 0.88 & 0.41 \\
\hline Leg perimeter, cm & 120.87 & 120.86 & 1.24 & 0.79 \\
\hline Length of pelvic limb, $\mathrm{cm}$ & 57.18 & 56.50 & 1.04 & 0.84 \\
\hline Carcass length, cm & 131.95 & 131.52 & 0.95 & 0.70 \\
\hline Thoracic depth, cm & 37.75 & 37.76 & 0.80 & 0.42 \\
\hline
\end{tabular}

MS: Mineral supplementation; SS, Strategic supplementation. SEM: Standard error of mean. ${ }^{a}$ Conformation score: 1 = Very convex, 2 = Convex, 3 = Rectilinear, 4 = Concave, 5 = Very concave; ${ }^{b}$ Finish score: 1 = Extremely abundant, 2 = Abundant, 3 = Medium, 4 = Slight, 5 = Scarce; 'Maturity: carcass within the 100-199 maturity range score represents the youngest group (100 is equal to A00 and 199 is equal to A99); 200-299: represent carcasses with intermediate, more advanced maturity (200 is equal to B00 and 299 is equal to B99); ${ }^{d}$ Adipose maturity based on fat color: 1 = Ivory white, 2 = Creamy white, 3 = Light yellow, 4 = Intense

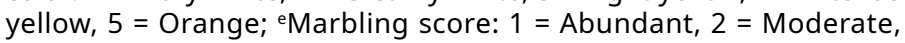
$3=$ Small, 4 = Slight, 5 = Traces, $6=$ Practically devoid. 
Responses to implants and supplementation of grazing bulls / Huerta-Leidenz et al.

was inconsistent, presumably because the production of natural hormones would already be sufficient to promote growth [22].

However, this explanation is not conclusive because bulls implanted with ATB or zeranol have presented lower levels of testosterone, reaching puberty 12 weeks later than not implanted counterparts [18]. Concentration and/or administration modes have shown to affect the bulls' response to the anabolic. The effectiveness of boldenone undecylenate on the final LW and ADG of fattened bulls has been reported [12] to be dose-dependent resulting significantly different from the control when the compound was injected at the highest dose [1 mililiter $\left.(\mathrm{mL}) \cdot 45 \mathrm{~kg}_{\text {of LW}}{ }^{-1}\right]$.

\section{Comparison of implant regimens for carcass traits}

Except for the thoracic depth, carcass traits did not vary significantly with the implant regimen. Carcasses of bulls implanted with RevalorRalgro exhibited deeper thoracic cavities $(P<0.01)[38.4$ centimeters (cm)], $4 \mathrm{~cm}$ more than those from the Ralgro-Ralgro group $(37.08 \mathrm{~cm})$ with a standard error of the mean of $0.75 \mathrm{~cm}$ (values not presented in tabular form). The significance of this single finding is imponderable because no precedent was found in this regard; but it could suggest differences in muscle distribution in the forequarters.

\section{Carcass classification/grading of the experimental groups}

The chi square test did not detect significant differences $(P>0.05)$ between the category / grade frequencies for the different treatments. The TABLE VI shows the distribution of these frequencies. In general, the carcass sample had a poor grading performance in quality, indicated by: (a) predominance of category $B$, the second in quality for bull carcasses by Venezuelan standards; (b) $52 \%$ were "Bullocks" (bulls under 30 mo of age) that did not exceed the fourth USDA quality (Standard) grade; and (c) $48 \%$ were carcasses with B or more advanced maturity ('Bulls"), which are not eligible to be quality-graded in the USA. [35]. In compensation, the sample performed outstandingly in the U.S. Department of Agriculture (USDA) yield grade (USDA-YG), reaching the top two yield grades (USDA-YG 1 and USDA-YG 2) with superior yield capabilities in boneless lean cuts.

The results of the present trial agree with other reports reporting carcass grades for fed entire males where the "Bulls" of "Bullocks" with Bos indicus influence, hardly exceeded the USDA-Standard grade, but exhibited the top USDA yield grades [16, 36].

TABLE VI

Frequency distribution of carcass categories / grades according to supplementation type and implant regimen

\begin{tabular}{|c|c|c|c|c|}
\hline \multirow{2}{*}{$\begin{array}{c}\text { Carcass category/ } \\
\text { grade }\end{array}$} & \multicolumn{2}{|c|}{ Supplementation $^{1}$} & \multicolumn{2}{|c|}{ Implant regimen ${ }^{2}$} \\
\hline & MS n (\%) & SS n (\%) & RAL-RAL n (\%) & REV-RAL $\mathrm{n}(\%)$ \\
\hline \multicolumn{5}{|c|}{ Venezuelan carcass category ${ }^{3}$} \\
\hline$A$ & $4(7.0)$ & $3(7.1)$ & $3(6.0)$ & $4(8.2)$ \\
\hline $\mathrm{B}$ & 33 (57.9) & $30(71.4)$ & $30(60.0)$ & $33(67.3)$ \\
\hline \multirow[t]{2}{*}{$\mathrm{C}$} & $20(35.1)$ & $9(21.4)$ & $17(34.0)$ & $12(24.5)$ \\
\hline & \multicolumn{2}{|c|}{$X^{2}=2.23 ; P=0.32$} & \multicolumn{2}{|c|}{$\chi^{2}=1.13 ; P=0.56$} \\
\hline \multicolumn{5}{|c|}{ USDA carcass quality grades ${ }^{4}$} \\
\hline High Standard & $4(7.0)$ & $4(9.5)$ & $4(8.0)$ & $4(8.2)$ \\
\hline Low Standard & $21(36.8)$ & $22(52.4)$ & $18(36.0)$ & $25(51.0)$ \\
\hline \multirow[t]{2}{*}{ Bull } & $32(56.1)$ & $16(38.0)$ & $28(56.0)$ & $20(40.8)$ \\
\hline & \multicolumn{2}{|c|}{$\chi^{2}=3.15 ; P=0.20$} & \multicolumn{2}{|c|}{$X^{2}=2.46 ; P=0.29$} \\
\hline \multicolumn{5}{|c|}{ USDA carcass yield grades ${ }^{5}$} \\
\hline 1 & $32(56.1)$ & $21(50.0)$ & $29(58.0)$ & $24(49.0)$ \\
\hline 2 & $25(43.9)$ & $20(47.6)$ & $21(42.0)$ & $24(49.0)$ \\
\hline \multirow[t]{2}{*}{3} & $0(0.0)$ & $1(2.4)$ & $0(0.0)$ & $1(2.0)$ \\
\hline & \multicolumn{2}{|c|}{$X^{2}=1.66 ; P=0.43$} & \multicolumn{2}{|c|}{$X^{2}=1.60 ; P=0.45$} \\
\hline Total & 57 & 42 & 50 & 49 \\
\hline
\end{tabular}

'MS: Mineral supplementation; SS: Strategic supplementation; ${ }^{2}$ RAL-RAL: corresponds to double-dosis implant (72 mg) of Ralgro ${ }^{\circledR}$ at day 0 followed by a second dosis of $72 \mathrm{mg}$ of Ralgro ${ }^{\circledR}$ at day 90 . REV-RAL: corresponds to a first dosis of Revalor ${ }^{\circledR}$ at day 0 , followed by a second dosis (72 mg) of Ralgro ${ }^{\circledR}$ at day $90 ;{ }^{3} \mathrm{~A}$ and B Venezuelan carcass categories correspond to the second - and third-quality, respectively; ${ }^{4}$ Carcasses of bulls younger than 30 mo. of age and (or) exhibiting an A physiological maturity are designated in the "Bullock" class, USDA Standard quality grade corresponds to the fourth quality, for bullock carcasses; ${ }^{5}$ USDA yield grades (YG) are rated numerically, namely 1, 2, 3, 4, and 5; a YG 1 carcass is expected to have the highest proportion (> 53.5 \%) of boneless, closely-trimmed retail cuts, while a YG 5 carcass is expected to have the lowest proportion $(<44.3 \%)$ of boneless, closely-trimmed retail cuts. 


\section{CONCLUSIONS AND IMPLICATIONS}

Both implant regimens are comparable in their effects on the fattening performance and commercially important carcass traits of grassfed bulls. The main limitation of the present study was the absence of a control (non-implanted) group to quantify the effects of the two implant regimes on the response variables under study. Strategic supplementation proves to be a feasible practice to adopt in low-plains pastures to improve the fattening performance of bulls, but its impact on the overall quality of the carcass is expected to be marginal. From bulls thus implanted and supplemented, one can only expect very lean carcasses with high potential for cutout performance, but value adding will be extremely difficult if a yield grading system is not in place.

\section{FUNDING}

This research was funded by the Fondo Nacional de Ciencia, Innovación y Tecnología (FONACIT) de Venezuela and the Consejo de Desarrollo Científico y Humanístico de la Universidad del Zulia (CONDES-LUZ).

\section{ACKNOWLEDGMENTS}

The authors thank the staff of Hato Santa Luisa Co. for their support during the experimental trial and Matadero CentroOccidental (MINCO) for their valuable assistance during cattle harvesting and carcass evaluation.

\section{CONFLICT OF INTEREST}

The authors declare no conflict of interest.

\section{BIBLIOGRAPHIC REFERENCES}

[1] ARAUJO-FEBRES, O. Los promotores de crecimiento (implantes) en el ganado bovino. En: O. Araujo-Febres (Ed.). Tópicos especiales en la nutrición de rumiantes. Editorial Astro Data. Maracaibo. Pp. 167-193. 2014.

[2] ARAUJO-FEBRES, O.; FERNÁNDEZ, M. C. Efecto en novillos del Monensin y el nivel de fibra de la dieta sobre el consumo y la digestibilidad de la materia seca. Rev. Fac. Agron. (LUZ): 8: 143-153. 1991.

[3] ARIAS, R.; SANTA-CRUZ, C.; VELÁSQUEZ, A. Effect of High Potency Growth Implants on Average Daily Gain of GrassFattened Steers. Animals. 9: 587. 2019.

[4] BENTO, C. B. P.; AZEVEDO, A. C.; GOMES, D. I.; BATISTA, E. D.; RUFINO, L. M. A.; DETMANN, E.; MANTOVANI, H. C. Effect of protein supplementation on ruminal parameters and microbial community fingerprint of Nellore steers fed tropical forages. Animals. 10(1): 44-54. 2016.

[5] BYERS, F.M.; HUERTA-LEIDENZ, N.O.; RODRÍGUEZ-MATOS, C.; ORDOÑEZ, J.; AVELLANEDA, J.F.; STONE JR., G. Strategic nutritional management technologies for enhancing forage beef production in the tropical Venezuelan llanos. Arch. Latinoam. Prod. Anim. 5 (Suppl. 1): 177-179. 1997.

[6] CONNELL, J.; HUERTA-LEIDENZ, N.; RODAS-GONZALEZ, A. Respuesta a la tipificación en pie, suplementación y anabolizantes de becerros en crecimiento a sabana. Arch. Latinoam. Prod. Anim. 10(3): 156-163. 2002.
[7] COMISIÓN VENEZOLANA DE NORMAS INDUSTRIALES (COVENIN). Carne de Bovino. Definiciones generales. Norma venezolana COVENIN 435-82.C.D.U. 636.2:337.5. Caracas, Venezuela. 1982.

[8] DELCURTO, T; HESS, B; HUSTON, J; OLSON, K. Optimum supplementation strategies for beef cattle consuming low-quality roughages in the western United States. J Anim. Sci. 77 (Suppl E):1-16. 2000.

[9] DEPABLOS, L.; ORDÓÑEZ, J.; GODOY, S.; CHICCO, C.D. Suplementación mineral proteica de novillas a pastoreo en los Llanos Centrales de Venezuela. Zoot. Trop. 27(3): 249-262. 2009.

[10] DETMANN, E.; VALENTE, É. E. L.; BATISTA, E. D.; HUHTANEN, $P$. An evaluation of the performance and efficiency of nitrogen utilization in cattle fed tropical grass pastures with supplementation. Livest. Sci. 162: 141-153. 2014.

[11] DEVELOPMENT CORE TEAM R: A Language and Environment for Statistical Computing. Vienna, Austria: R Foundation for Statistical Computing. Version 3.6. https://bit.ly/3wFcoJK. 2020.

[12] ELSHARAWY, N.T.; AHMED, A.E.; HARIDY, M.; KASSAB, A.Y.; HAMDON, H.A. Safety range of Boldenone Undecylenate injection in beef bulls. Biosci. Res. 16(2): 1556-1564. 2019.

[13] FONDO NACIONAL DE CIENCIA, INNOVACIÓN Y TECNOLOGÍA(FONACIT). Código de Bioética y Bioseguridad. Ministerio del Poder Popular para Ciencia y Tecnología. 3ra. Ed. 63 pp. 2008.

[14] GARG, M.R. Role of bypass protein in feeding ruminants on crop residues based diets Review A.J.A.S. 11 (2):107-116. 1998.

[15] HUERTA-LEIDENZ, N.; ALVARADO, E.; MARTÍNEZ, L.; RINCÓN, E. Conformación, acabado y características biométricas de la canal de diferentes clases de bovinos sacrificados en el Estado Zulia. Rev. Fac. Agron. (LUZ). 5: 522-536. 1979.

[16] HUERTA-LEIDENZ, N.; RUIZ-FLORES, A.; VALERIOHERNANDEZ, J.; JEREZ-TIMAURE, N.; RODAS-GONZALEZ, A. Bullock carcass performance trends in Brahman and $F 1$ crosses fattened on tropical pastures. NACAMEH. 14 (1):1630. 2020.

[17] JEREZ-TIMAURE, N.; HUERTA-LEIDENZ, N. Effects of breed type and supplementation during grazing on carcass traits and meat quality of bulls fattened on improved savannah. Livest. Sci. 121, 219-226. 2009.

[18] JONES, S. J.; JOHNSON, R. D.; CALKINS, C. R.; DIKEMAN, $M$. Effects of trenbolone acetate on carcass characteristics and serum testosterone and cortisol concentrations in bulls and steers on different management and implant schemes. J Anim. Sci. 69:1363 - 1369. 1991.

[19] LABRUNE, H. J.; REINHARDT,C. D.; DIKEMAN, M,. E.; DROUILLARD, J.S. Effects of grain processing and dietary lipid source on performance, carcass characteristics, plasma fatty acids, and sensory properties of steaks from finishing cattle. J. Anim. Sci. 86:167-172. 2008. 
Responses to implants and supplementation of grazing bulls / Huerta-Leidenz et al.

[20] LACHMANN, M.; BORTOLIN, E.; LOSADA, F.; ROMERO, M.; ARAUJO-FEBRES, O. Influencia del nivel de nitrógeno suplementado sobre el consumo, la digestibilidad y la ganancia de peso en novillos alimentados con heno de sorgo y alimento concentrado. Rev. Fac. Agron. (LUZ). 14: 665-671. 1997.

[21] LASCANO, C.E. Harry Stobbs Memorial Lecture: Managing the grazing resource for animal production in tropical America. Trop. Grassl. 25: 66-72. 1991.

[22] MACKENZIE, J.R. Effects of zeranol implant on behavior, growth rate, and carcass characteristics of Friesian bulls. New Zealand J. Exp. Agricul. 11: 225-229. 1983.

[23] MORON - FUENMAYOR, O.; ARAUJO-FEBRES, O.; RINCON - URDANETA, E. Efecto del implante, de la castración y mestizaje en toretes mestizos comerciales a pastoreo con suplementación. Rev. Fac. Agron. (LUZ). 9:49-62. 1992

[24] MORON-FUENMAYOR, O.; ARAUJO-FEBRES, O.; BRILLEMBOURG, D. Efecto de la condición sexual y del implante con ATB+17b-estradiol sobre el crecimiento de animales mestizos Santa Gertrudis. Rev. Fac. Agron. (LUZ). 11:81-87. 1994.

[25] MORÓN-FUENMAYOR, O.; ARAUJO-FEBRES, O.; HUERTALEIDENZ, N.; RINCÓN, E. Efecto de los agentes anabólicos sobre la ceba a corral y las caracteristicas de la canal de toretes mestizos Santa Gertrudis. Rev. Fac. Agron. (LUZ). 10: 325-342. 1993.

[26] NATIONAL RESEARCH COUNCIL (NRC). Nutrient Requirements of Beef Cattle,National Academies Press, Washington, D. C. Pp. 40-46. 2000.

[27] PLASSE, D.; FOSSI, H.; HOOGESTEIJN, R.; VERDE, O.; RODRÍGUEZ, M.C.; ROdRÍGUEZ, R. Producción de vacas $F_{1}$ Bos taurus $\times$ Brahman apareadas con toros Brahman y de vacas Brahman con toros $\mathrm{F}_{1}$ Bos taurus $\mathrm{x}$ Brahman versus Brahman. 1. Pesos al nacer, destete, 18 meses y peso final. Livest. Res. Rural Develop. 12 (4): 14. 2000.

[28] REPÚBLICA DE VENEZUELA. Decreto Presidencial No. 1896. Ministerio de Agricultura y Cría. Gaceta Oficial de la República de Venezuela No 36.242. Caracas Venezuela. 4 pp. 1997.

[29] RIERA-SIGALA, T.J.; RODAS-GONZÁLEZ, A.; RODRÍGUEZMATOS, C.; AVELLANEDA, J.F.; HUERTA-LEIDENZ, N. Growth traits and carcass weights of purebred Brahman and F1 Brahman $x$ Bos taurus bulls raised and fattened semiintensively on improved savannah. Arch. Latinoam. Prod. Anim. 12: 66-72. 2004.
[30] RIERA, S.T. Crecimiento y características de toros de cinco tipos raciales y el efecto de tecnologías postmortem sobre la calidad de la carne. Universidad Rafael Urdaneta. Maracaibo, Venezuela. Tesis de Grado. 86 pp. 1994

[31] RODAS-GONZÁLEZ, A.; HUERTA-LEIDENZ, N.; JEREZTIMAURE, N. Benchmarking Venezuelan quality grades for grass-fed cattle carcasses. Meat Muscle Biol. 1(1): 1-80. 2017.

[32] SMITH, J.K.; CHACÓN-MORENO, E.J.; JONGMAN, R.H.G.; WENTING, P.H.; LOEDEMAN, J.H. Effect of dyke construction on water dynamics in the flooding savannahs of Venezuela. Earth Surf. Process. Landforms. 31: 81-96. 2006.

[33] SMITH, Z. K.; JOHNSON, B.J. Mechanisms of steroidal implants to improve beef cattle growth: a review. J. Appl. Anim. Res. 48(1): 133-141. 2020.

[34] TEJOS, M.R.; MEJÍAS, N.; PÉREZ, Y.; AVELLANEDA, J.F. Manejo de pasturas y producción de carne en el llano bajo de Venezuela. 2005. IX Seminario de pastos y forrajes. Asociación Venezolana de Producción Animal. Pp. 171-181. En Línea: https://bit.ly/3xmJFtl. 13/11/2020

[35] UNITED STATES DEPARTMENT OF AGRICULTURE (USDA). Official United States standards for grades of carcass beef. 2017. Agricultural Marketing Service, Washington, D.C. On Line: https://bit.ly/3wyFM4I. 30/03/2021.

[36] VAZQUEZ-MENDOZA, O.V.; ARANDA-OSORIO, G.; HUERTABRAVO, M.; KHOLIF, A.E.; ELGHANDOUR, M.M.Y.; SALEM, A.Z.M.; MALDONADO-SIMÁN, E. Carcass and meat properties of six genotypes of young bulls finished under feedlot tropical conditions of Mexico. Anim. Prod. Sci. 57: 1186-119. 2017.

[37] VEDOVATTO, M.; PEREIRA, C. S; BELTRAME, J. A. M.; NETO, I. M. C.; BENTO, A. L. L.; MARTHA, G. O. D.; MORAIS, M. G.; FRANCO, G. L. Inclusion of concentrate and growth promoters' additives in sheep diets on intake, digestibility, degradability, ruminal variables and nitrogen balance. Rev. Mex. Cien. Pec. 11(1):132-152. 2020.

[38] WANAPAT, M; FOIKLANG, S.; ROWLINSON, P.; PILAJUN, $R$. Effect of carbohydrate sources and cotton seed meal in the concentrate: II. Feed intake, nutrient digestibility, rumen fermentation and microbial protein synthesis in beef cattle. Trop. Anim. Health Prod. 44: 35-42. 2012.

[39] WANG, L.M. Investigation of Alternatives to lonophore/ Antibiotic Management Strategies in Finishing Cattle and the Inherent Effect on Beef Quality and Shelf Life. University of Guelph, Guelph, Ontario, Canada. Thesis of Grade. 149 pp. 2019. 